\section{Engelsk stof i \\ Illustreret Familie Journal \\ under 1. verdenskrig \\ og i mellemkrigstiden}

Af cand.polit. Verner E. Andersen

$\mathrm{N}$ ogle mennesker læser fortrinsvis bøger, nogle læser aviser, nogle læser ugeblade o.lign., nogle læser lidt af hvert og nogle læser slet ingenting.

Der findes mange litteraturhistorier på dansk. Der findes også adskillige værker om dansk dagspresse både generelt og om de enkelte aviser. Men om danske ugeblades historie findes der kun få værker som f.eks. Dansk Mediehistorie. Store gamle danske ugeblade som Hjemmet og Illustreret Familie Journal (herefter FJ) er kun beskrevet i artikler og har aldrig fået deres egne monografier. Om ugebladene - den vel mest læste del af den danske trykte kulturarv, måske fraset aviser - er der imidlertid brug for en alternativ kulturhistorie.

Inger Simonsen, Vibeke Stybe og Mette Winge har skrevet fine værker om børnebogens historie i Danmark. Erland Munch-Petersen har skrevet om trivialromanens historie i forrige århundrede. Knud Nielsen har fortalt om de kulørte hefter i 1920'erne og 1930'erne. Der findes flere bøger om tegneserier i Danmark. Men - om ugebladene findes næsten kun bøger/artikler om udgivernes historie, ikke om udgivelsernes historie. Måske grundmaterialet: de tusindvis af sider gennem årene, afskrækker?

For øjeblikket tales der meget om amerikansk mediedominans. Men udenlandsk påvirkning via medierne er naturligvis ikke noget nyt fænomen i et lille land.

Nedenfor søges påvist en næsten ikke erkendt, men stille, rolig og vedholdende påvirkning i mellemkrigstiden - måske ikke mindst af børn og unge - et helt andet sted fra, nemlig Storbritannien. Påvirkningen kom bl.a. gennem FJ. Englænderne W.O.G. Lofts og D.J. Adley har undersøgt historien bag en stor del af engelsk triviallitteratur, ikke mindst for børn. De havde adgang til arkivmateriale hos den dengang vel nok største engelske forlægger af den slags litteratur, Amalgamated Press Ltd., London, som også var hovedleverandør til FJ. F.eks. kunne Lofts og Adley sætte forfatternavn på en mængde anonyme fortællinger via Amalgamated Press' honorarprotokoller.

Herhjemme har det været afgørende for de store bogværker om Berlingske Tidende, Politiken og Morgenavisen Jyllandsposten, at forfatterne kunne trække på udgivernes arkiver. Ville man lave en bog om Hjemmets historie - dets indhold - måtte Egmonts arkiv være særdeles værdifuldt.

Arkivet hos udgiveren af FJ, Aller Press A/S, har været yderst imødekommende og venligt over for mig. Men arkivets muligheder for at belyse FJ's historie i mellemkrigstiden er små, fordi Carl Allers Etablissement A/S i Valby blev totalt ødelagt ved Schalburgtage (eller Hipotage, som FJ kaldte det) den 23. januar 1945. 
Hvordan kontakten mellem Aller og de engelske leverandører kom i stand, hvad det udenlandske stof kostede, f.eks. i forhold til dansk produceret stof, er det, uden FJ's arkiv, svært at sige i dag. Amalgamated Press (i 1960'erne: J.P.C., London) kørte desværre ret hurtigt træt af mine spørgsmål, uanset flere stilfærdige rykkere. - Måske brugte FJ meget engelsk stof, fordi det var billigere. Måske var det engelske stof rigeligere og bedre, mens den danske kreativitet endnu ikke rigtigt var kommet i gang. Måske begge dele.

Da størstedelen af de for undersøgelsen relevante blade aldrig solgtes i Danmark, har jeg i stedet prøvet at finde engelske originaler til stof i FJ på British Library's afdeling i Colindale nær London for dermed at dokumentere forbindelsen. Den engelske blad- og magasinproduktion var og er imidlertid umådelig efter danske forhold, ligesom der her er tale om en ca. 25-årig periodes udgivelser, så der er stadig meget at gennemgå. Samtidig er mængden af sider i FJ i den undersøgte periode også umådelig. Et groft skøn viser det:

1914 til 1925: 12 år à ca. 50 nr. à gennemsnitligt 40 sider $=24.000$ sider + 1926-1939: 14 år à ca. 50 numre à gennemsnitligt 50 sider $=35.000$ sider - ialt 26 årgange med ialt ca. 59.000 sider, uden særligt mange reklamer.

En periodeafgrænsning kan altid diskuteres. Det er naturligvis ikke sådan, at engelsk stof kun forekom i FJ 1914-39. Det var der både før og efter. Før 1914 var der f.eks. en del engelske noveller og romaner. Men koncentrationen af engelsk stof i FJ var meget udtalt
1914-39, sammenlignet med dansk stof af tilsvarende karakter samt materiale fra USA, Tyskland og - ret sporadisk Frankrig.

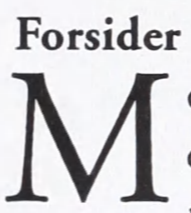
ens ugebladenes forsider nu om dage er 'spisesedler', hvor de mest spændende dele af bladenes indhold annonceres, var forsiderne førhen tegnede helsidesbilleder og i større format end det nu anvendte format.

FJ's forsider var overvejende dansktegnede af flere forskellige tegnere. Der var dog også svenske (fra FJ's søsterblad Allers), tyske (fra Fliegende Blätter) og amerikanske.

Sidst i 1930'erne forekommer en hel del engelsktegnede forsider, heriblandt de yndede Lawson Wood-tegninger af aber m.v. og af situationer med dyr i stenalderen. De forekom også som helsider inde bladet.

Andre engelsktegnede forsider, som der var mange af i 1935, var "anonyme" som det i højere grad var almindeligt dengang. Aller hentede bl.a. forsider fra det engelske magasin Britannia \& Eve både til sit kortvarige magasineksperiment Ultra i 1937 og til FJ. Britannia \& Eve's forside (en smuk kvinde) i nummeret for sept. 1936 blev til forsiden på FJ nr. 50 for 8. dec. 1936, og Britannia \& Eve’s forside (en smuk kvinde) i nummeret for nov. 1936 blev brugt som forside på $\mathrm{FJ}$ nr. 32 for 10 . aug. 1937. Men der var mange andre klart engelske, men uidentificerede forsider på FJ 1936, også før bladets modernisering i efteråret 1936. 


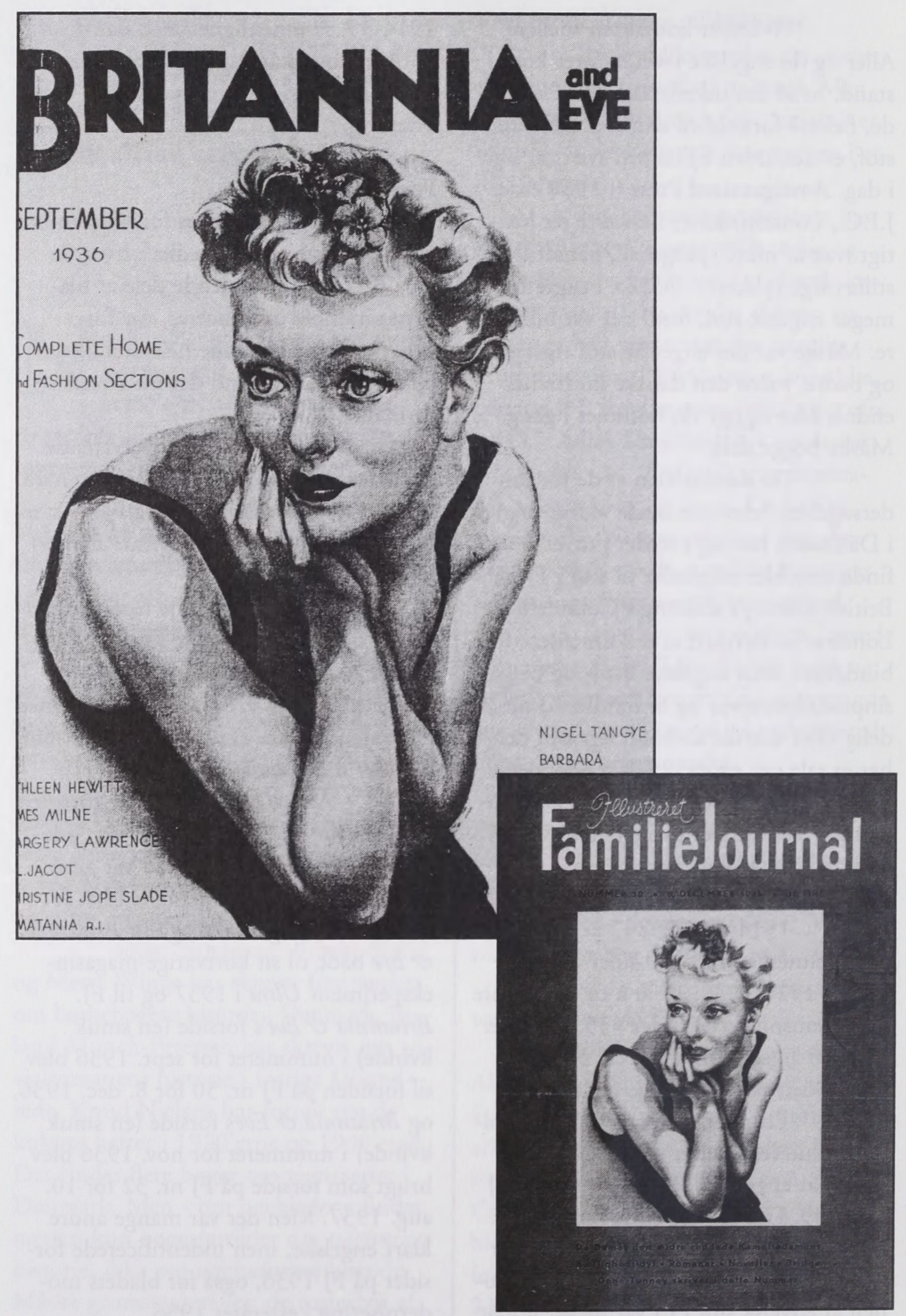


I 1939 er der stadig en del engelsktegnede forsider: seks af Lawson Wood, to af Gilbert Wilkinson (der tegnede meget i magasinet The Passing Show), to af Fred Purvis samt andre uidentificerbare engelske.

Generelt anførte FJ ikke navne på tegnerne af forsiderne, heller ikke de dansktegnede.

\section{Størrre og mindre fotos, tegninger og} malerier inde $\mathrm{i}$ bladet

I kke mindst i 1920'erne var der i FJ mange "separate" billeder, dvs. billeder med en selvstændig oplysende og underholdende funktion. Der var en hel del danske (Alfred Schmidt, Adolf Bock, P. Mønsted m.fl.), andre skandinaviske (vel fra Allers svenske og norske blade), tysk (f.eks. Felix Schwormstädts tegninger bl.a. fra København og Anton O. Fischer), italienske (Beltrame - sidst i 1920'erne og i 1930'ernes begyndelse) og amerikanske (helsider fra vittighedsblade, Gibson-tegninger m.v.)

Men det engelske islæt var kraftigt. Tegneren F(ortunio) Matania var en hyppig gæst i FJ.

Ofte var tegneres eller kunstforlags navne angivet, mens navne på det engelske blad eller magasin, hvor billedet måtte have forekommet, stort set var fraværende. Mange engelske tegninger, bl.a. fra spændende mindre begivenheder i Imperiet, er helt uden oplysninger om tegner eller anden identifikation.

Der var både tale om fortællende billeder og mere konkrete, bl.a. fra Illustrated London News, men uden kildeangivelse. Der blev også bragt dramatiske billeder f.eks. fra The Wide World
Magazine udgivet af George Newnes Ltd., London. Som det fremgår af den summariske liste i note 1 ), var der således i 1927-28 tale om intensiv brug af 'separate' billeder fra dette engelske magasin, uden kildeangivelse. En flittig læser af FJ blev, umærkeligt, velorienteret om store dele af engelsk historie og samfundsliv, både i underholdende og mere seriøs form som tekster til billederne.

Der var basis for en god del sympati for England, allerede inden Danmark blev besat i 1940 .

Der var selvsagt mange engelske, franske og tyske billeder, især tegninger, i FJ under 1. verdenskrig.

Mere detaillerede eksempler på engelske tegninger i FJ, særligt i det første ti-år af mellemkrigstiden:

1920

nr. 4, s. 3: Bal i London (F. Matania)

nr. 21, s. 3: Den spanske armada ødelægges (Caton Woodville, der har mange tegninger fra engelsk historie i FJ 1920 og 1921).

nr. 51, s.3: Fremtidens flyvemaskiner (Geoffrey Watson)

1925

nr. 5, s.9: På Motorcykle gennem Kannibalernes Land (tegner må være Stanley L. Wood; men er ikke anført).

nr.15, s.11: David Copperfields Rejse fra Yarmouth til London (F. Matania)

nr. 38, s.11: Det hemmelige Panel (af kampe mellem Hannoveranere og Stuarter; efter S. E. Wallers maleri med till. af Raphael Tuck \& Sons, London).

1930

nr. 3, s.7: Sagaen om Kong Arthurs Komme (efter maleri af WalterWest).

nr. 34, s. 11:Isbjørne i natbelysning i Londons Zoo (C.E. Turner).

nr. 5, s.3: Hundehvalp smadrer et æg (Lawson Wood). 


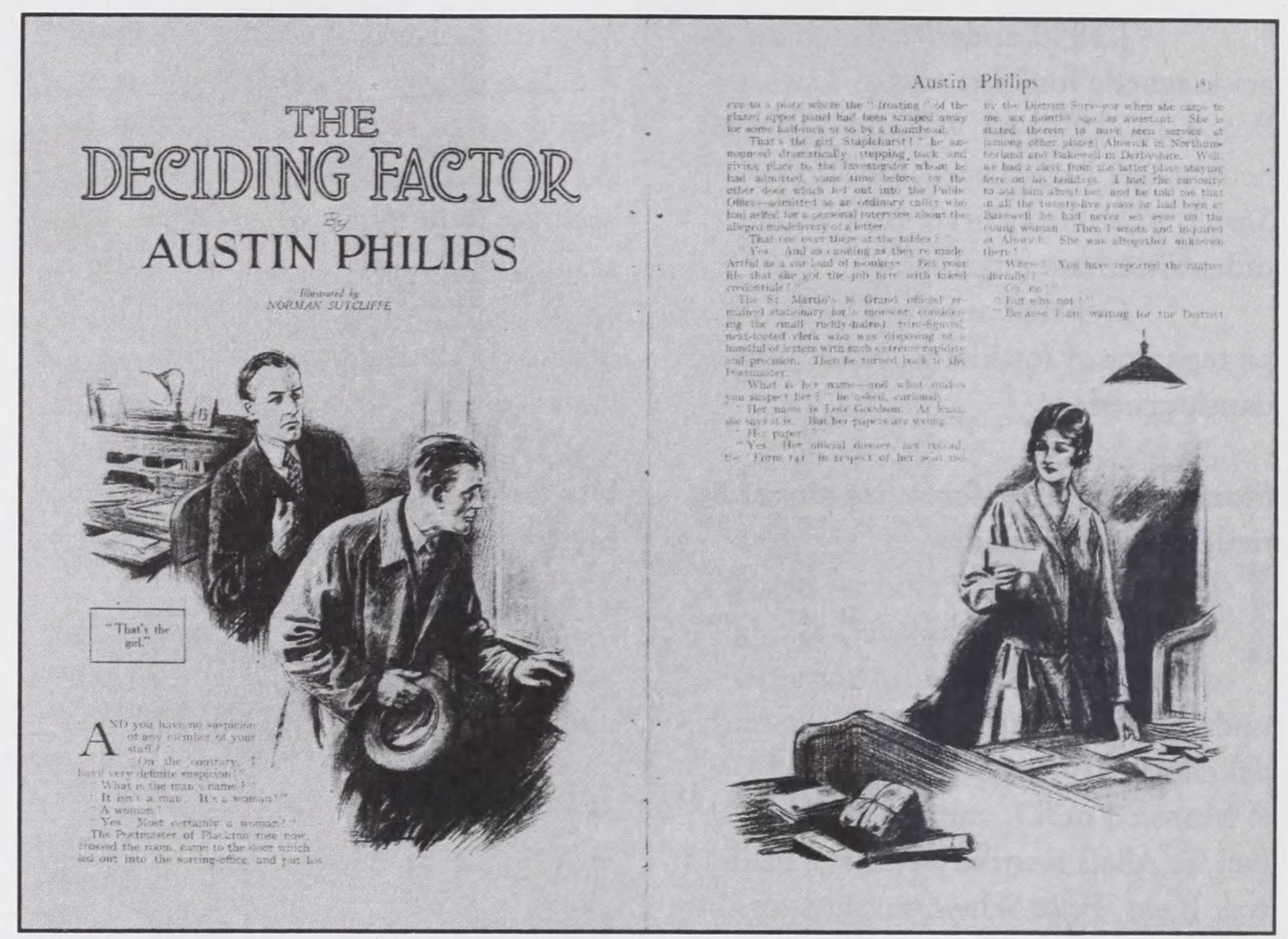

The Strand Magazine, February, 1928.

Illustreret Familie-Journal, 3, 1929.

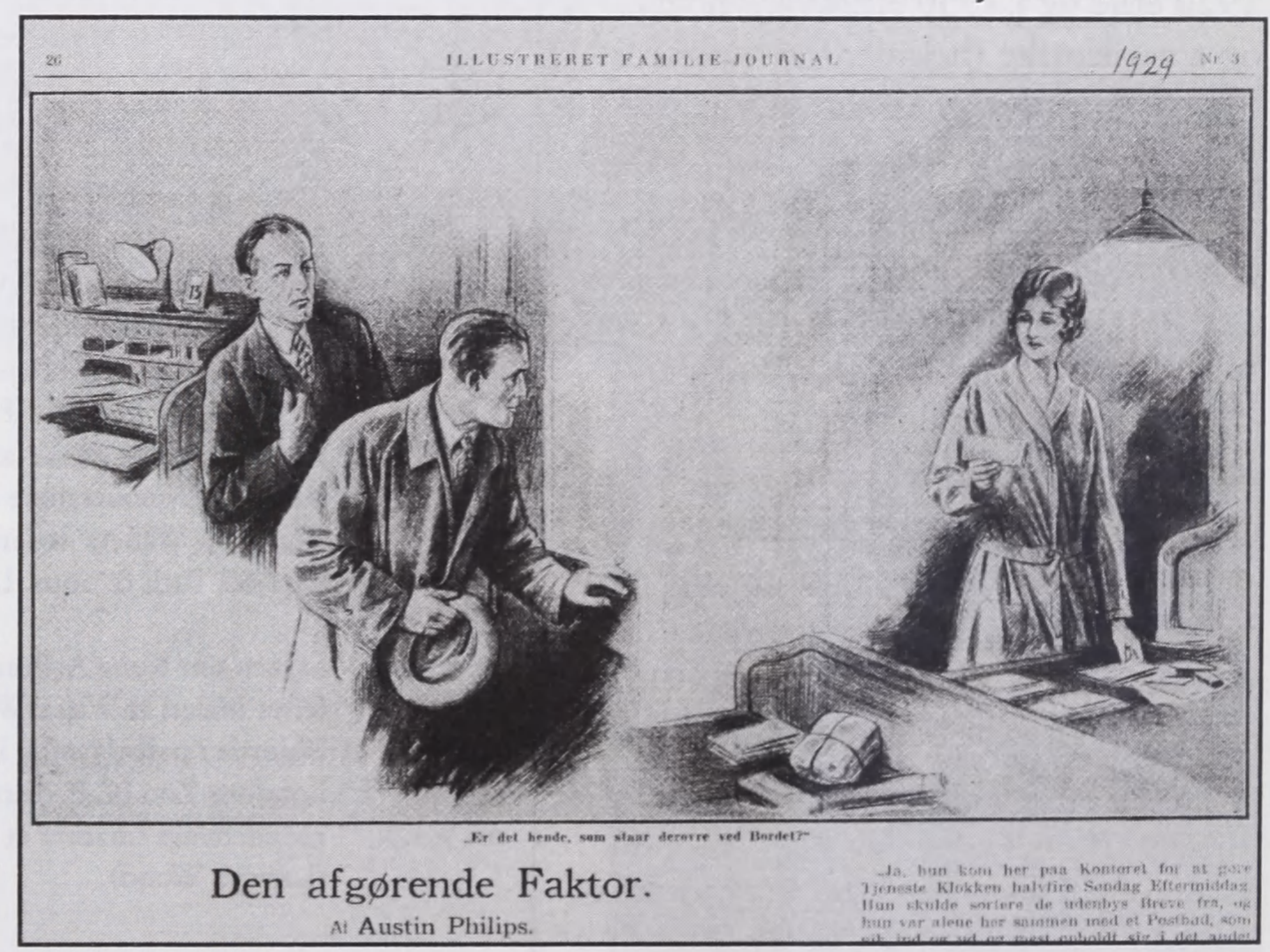


Antallet af engelske tegninger og malerier er aftagende i perioden, og i 1935 er der kun få engelske billeder.

I 1939 er der ikke længere engelske billeder som selvstændigt stof. Men der er nu en del store (spids)artikler om engelske forhold.

\section{Romaner og eventuelle illustrationer}

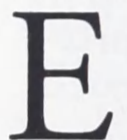
ngelske romaner spillede en stor rolle i FJ og vandt sammen med engelske noveller, småbørnshistorier og vittighedstegninger indpas $\mathrm{i}$ bladet betydeligt før, de engelske tegneserier dukkede op. I årgang 1887 er der flere engelske romaner, bl.a. af Rider Haggard. I årgang 1914 er der romaner af L.G. Moberly, Charlotte M. Brame og Charles Garvice.

I den undersøgte periode bragte FJ ofte romaner af den tyske forfatterinde Courths-Mahler, og senere kom danske romaner til.

Romanforfatternes navne angives konsekvent, mens tegneres navne først oplyses i 1930'erne. Ofte er der ingen tegninger. Til afgørelse af, at romanerne er engelske og ikke amerikanske, er der kigget nærmere i teksten samt på tegnernes signaturer, hvor der er tale om ikke-danske illustrationer. Nedenstående liste viser, at der i hele perioden er tale om en hyppig anvendelse af engelske romaner. Det er ikke urimeligt at antage, at læsning af disse romaner har givet en glidende indføring i og forståelse for engelsk miljø hos navnlig engelsk overklasse. Engelske stednavne, titler og personnavne er bibeholdt $\mathrm{i}$ overvejende grad i oversættelserne. Der kan hos læseren opstå en opfattelse af, at
England er landet, "hvor det foregår". Læseren bliver engelskvenlig.

Eksempler på FJ's engelske romaner, med forfatterens navn i parantes, og idet ut betyder uden tegninger:

\section{0}

1-14 Antigone (L.T. Meade) ut

21-31 Hadets Hammer (Guy Thorne) ut 44-1921:6 Formørket Lykke (E.A. Rowlands ) ut

1925

3-17 Den gyldne Tid (May Wynne) ut 29-1926: 4 Violinstrenge (John Haslette Vahey) ut

45-1926: 17 En salsom Overenskomst $(\mathrm{H}$. Beach-Webb) ut

1930

3-26: Fingeren, der skriver (E. Normann Torry; foromtale i nr . 2, 1930) med tegninger af en af FJ's danske "hustegnere": Georg Tormer

13-34 En Filmsstjerne ( Paul Trent) ut

38-52 Fu Manchus Datter (Sax Rohmer pseudonym for Arthur Sarsfield Ward, foromtale i nr . 37, 1930) med flotte, men anonyme engelske tegninger.

1935

14-33 Hendes forste karlighed (Ruby M. Ayres) - med tegninger af en anden af FJ's faste tegnere: Magnus Kristensen

16-28 Den vilde Jagt (Dornford Yates) ut.

33-43 Kun ikke Karlighed (Jennifer Ames) - med tegninger af danskeren Aslaug Tranheim. FJ har bragt $\mathrm{i}$ hvert fald 4 romaner af Jennifer Ames.

1937

Dette år bragte $\mathrm{FJ}$ udover andre romaner, 4 engelske romaner med engelske tegninger, nemlig Måne 
over Stambul (Anne Duffield) og Marokkaneren (Dorothy Buck) begge med tegninger af Stanley Davis - samt Kompromitteret og To Skabner (Mary Burchell) - begge med tegninger af Frank Oldham. Tegningerne er flotte, men i den uniforme, lidt lækre engelske magasinstil.

1939

6-18 Tre mand og en kvinde (E. W. Savi) - med tegninger af den faste FJ-tegner Henrik Hansen.

8-16: Alt for letsindig (Mary Burchell) med tegninger af den faste FJtegner Aslaug Tranheim.

18-34 Blodrode Stjerner (Barbara Heygate) - med tegninger af endnu en "hustegner" hos FJ: Poul Bech.

1940 I foråret bringes endnu en roman med tegninger af englænderen Stanley Davis, nemlig Eventyrerske (Dorothy Black).

\section{Noveller som oftest med illustrationer T ens FJ bragte en del tyske ro- M maner, sås tyske noveller næ- sten aldrig i perioden. Enkelte} franske blev trykt, ligesom amerikanske noveller vandt frem i 1930'erne. Danske noveller var der hele tiden; i begyndelsen var de korte. Men hovednovellen i numrene i 1920 'erne var næsten altid engelsk og næsten altid med engelske tegninger. I 1930'erne var engelske noveller fortsat fremtrædende - nu oftere med danske tegninger.

Forfatternavne blev altid angivet. I 1920'erne var en hel del noveller oversat af fru Greve hos Aller (" $\mathrm{g}$ " under novellen). Særdeles mange var oversat af P. Jerndorff-Jessen, hvilket anførtes over novellen.

Også andre oversættere er nævnt. Men i 1935 angives oversættere ikke mere. Ved en vurdering af forfatternavn, en angivet oversætter samt personnavne m.v. i teksten var de fleste læsere nok klar over novellens "hjemland", men den engelske oprindelse (magasin/forlægger i England) fremgik ikke. Det var vel også overflødigt for formålet. Først fra og med FJ nr. 27, 1936 anførtes de engelske tegneres navne. Denne nye praksis omtaltes ikke. FJ undgik helt jagt, boksning m.v., jvf. note 2)

Til belysning af FJ's brug af engelske noveller nævnes:

1920: I stort set hvert nr. er der en engelsk novelle med engelske tegninger. Der er også korte danske noveller.

1925: Som 1920. De danske noveller er dog lidt længere.

1927, 1928 og 1929: I den summariske liste i note 3) er nævnt mange eksempler på engelske noveller i FJ fra disse år og deres engelske oprindelse.Denne fremgår ikke udtrykkeligt af FJ. The Strand Magazine, hvori Conan Doyle's Sherlock Holmes-historier iøvrigt blev offentliggjort, blev udgivet af George Newnes Ltd., London. - På grundlag af listen, der også omfatter lidt fra bl.a. 1936 og 1937, kan FJ's redigeringspraksis og valg af illustrationer følges præcist af interesserede. - At The Strand Magazine optræder helt overvejende som leverandør i note 3), kan være en tilfældighed, idet jeg mest har haft dem til rådighed.

1930: Der er engelske noveller i næsten hvert nr. og næsten altid med engelske tegninger. Rafael Sabatinis novelle Et bryllup 
på Skafottet har flotte engelske tegninger af Greenup, ligesom der i slutningen af 1930 er fem Kaptajn Blod sørøverhistorier af Sabatini med tegninger af Greenup. Dennes navn er ikke angivet, men kan findes på tegningerne.

1935: Der er engelske noveller i næsten hvert nr. og næsten altid med engelske tegninger. Men derudover er der mange engelske noveller med danske tegninger. 1936 og 1937: Der henvises til note 3) og bemærkningerne ad 1927, 1928 og 1929. 1939: I næsten hvert nr. er der engelske noveller, men nu oftest med danske tegninger. Kun 12 noveller har engelske tegninger. Iøvrigt kan man måske ikke helt afvise, at nogle af novellerne med danske tegninger - til imødekommelse af en tendens i tiden - kan være skrevet af danskere under pseudonym. Bl.a. Niels Meyn skrev under utallige pseudonymer, både børnebøger og krimihistorier i de "Kulørte hæfter" dengang.

\section{Ungdomsromaner - normalt med illustrationer}

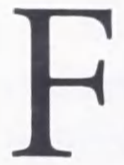

$J$ bragte en ungdomsroman af Niels Meyn i sommeren 1919. Igen i sommeren 1920 kom der en, nu anonym, sommerferiehistorie. I 1921 og 1923 var der ingen sommerferiehistorier. I 1922 og 19241926 kom der hvert år en sommerferiehistorie, men ellers ingen ungdomsroman. Den var dansk, men anonym, og var ledsaget af vejledning til bygning af en hytte eller et sørøverskib el.lign. til inspiration for en leg à la den pågældende historie. Til selve historien var der danske illustrationer. Sommerferiehistorierne bragtes fast hvert år til og med 1937. Kun dette sidste år anførtes for- fatternavn: Knud Gatzwiller, som selv har sagt, at han også skrev de tidligere års sommerferiehistorier (med Sir Richard og Splinten).

Forfattere kunne eller være "skrivekuglen" Niels Meyn eller drengebogsforfatteren Ebbe Nielsen, der var beskæftiget hos FJ.

1927-1937 var ungdomsromanerne et helårsfænomen hos $\mathrm{FJ}$.

Måske gled de derefter ud, fordi Aller startede tegneseriebladet Skipper Skrak i 1938, hvori der var en ungdomsroman.

Fra 1919 til og med 1937 bragtes ialt 51 ungdomsromaner i FJ, heraf 18 danske. 17 af disse var sommerferiehistorier. De resterende 33 var alle engelske og helt overvejende med engelske illustrationer. FJ oplyser intetsteds, at der er tale om engelske historier og engelske tegninger.

Forfatternavn anføres ikke, ejheller oversætter.

Det engelske forlag var Amalgamated Press Ltd., der var en del af lord Northcliffe's bladimperium. Heller ikke Amalgamated Press angav normalt navn på forfatter eller tegner. Forfatternavne vedrørende fortællinger i Amalgamated Press' daværende kostskoleblade The Magnet og The Gem samt i bladet Chums var ofte pseudonymer. Det har givet engelske forskere af børnelitteratur en del bryderier.

Jeg har fundet følgende engelske originaler til FJ's ungdomsromaner:

1. Nr. 52, 1926 - 21, 1927: Historien om Trofast, Comic Life 1924: Rough the Roamer

2. 22-25, 1927: Kongens Vabnere, Comic 
Life 1927: The King's Guard

3. 39, 1927-10,1928: Det glade Firklover, Comic Life 1926: The Fourth Form at Stormcove

4. 35, 1928-10, 1929: Omar den Fredlose, Lot-ó-Fun: Omar, the Outlaw. Forfatter: H.B. Richmond: pseudonym for E. Newton Bungay; tegner: anonym

5. 35, 1929-13, 1930: Søkadetten, My Favourite 1928: A Middy of Nelson's Day.

6. 40, 1930-5, 1531: Det flammende Lyn, Chums 1930/31: Rogues of The "Roaring Glory"; forfatter: S(amuel) Walkey; tegner: Cecil Glossop

7. 5-22, 1931: Slottet med de 1000 Trappetrin, Lot-o'-Fun 1928:The Castle of the Thousand Steps

8. 34-40, 1931: Kaplobet til Månen, Chums 1931-32: The Nightmare Planet; forfatter: Earle Danesford, pseudonym for Francis Addington Symonds, som bl.a. skrev mange Sexton Blake-historier; tegner: anonym.

9. 45,1931-18, 1932: Junglens Hemmelighed, Lot-o'-Fun 1927: The Secret of the Jungle

10. 36, 1932-9, 1933: Barracuda, Chums 1931/32: Barracuda; forfatter Paul Corydon; tegner: Cecil Glossop.

11. 35-40, 1933: Lygtemanden, Chums Supplement forår 1932: Fosca the Fowler; forfatter: Alan Nation; tegner: anonym.

12.35, 1934-3, 1935: Havets Herskere, Chums Supplement forår 1932: Blake of the Whip Hand! forfatter: Piers Anson: pseudonym for Draycot Montagu Dell, redaktør af Chums. Tegner: Cecil Glossop

13. 5-23, 1935: De skibbrudne på Paradisoen, Crackers 1931-32; The Little Castaways

14. 37, 1936-5, 1937: I Piratflagets Skygge,
Modern Boy 1934: Spanish Death! forfatter: Vice-Admiral E.R.G.R. Evans, pseudonym for Edward Radcliffe Garth Russell, R.N., C.B., D.S.O.; tegner: anonym.

De under $1-5,7,9,13$ og 14 anførte børneblade blev udgivet af Amalgamated Press. Chums blev erhvervet af Amalgamated Press, der således også var udgiver af de ovenfor nævnte årgange af Chums med Chums Supplement. Til illustration af, hvad der kunne komme af engelsk påvirkning fra historier, der stammede fra Amalgamated Press, oplyses, at der nogen tid efter, at Chums var overtaget, blev sat et kraftigt markeret motto ind på en side foran $\mathrm{i}$ forlagsbindet, nær indholdsfortegnelsen, af følgende ordlyd: "To the Boys of the Empire upon which the Sun never sets". (Jfr. Chums 1929-30 og 1931-32).

\section{Småbørnshistorier - altid med illu-} strationer - samt udklipsting

D forsøgte naturligvis at dække hele familiens behov for historier - og aktiviteter. Altså måtte der også være eventyr/småbørnshistorier.

I mange år fyldte disse historier en halv side hver uge. De var næsten udelukkende ledsaget af engelske tegninger af den type, som var i Amalgamated Press' nursery comics.

I 1930'erne fik historierne den fineste fremtræden i FJ: helsides og med farveillustrationer, hvoraf mindst én altid var engelsk. Af og til kunne tegnernes navne ses. De var ofte kvinder.

I 1939 fik småbørnshistorierne dog mindre plads igen, og de stadig 
overvejende engelske tegninger var små. Historierne var ofte underskrevet $g$, d.v.s. fru Greve hos Aller. Nærmere undersøgelser må vise, om hun blot lod sig inspirere af de engelske tegninger til selv at forfatte en historie, eller oversatte og eventuelt forkortede de engelske originale historier eller måske skrev indholdet af tegneserier i Amalgamated Press' enorme og helt uoverskuelige ugentlige udbud af småbørnsblade sammen til historier. I begyndelsen og slutningen af perioden stod der hverken $g$. eller noget andet navn ved historierne. Tegneres navne var aldrig oplyst. Solister med navne i rampelyset tenderer jo mod at blive dyrere!

FJ's småbørnshistorier var fyldt med konger og prinsesser, alfer og troldmænd, drager, dværge og søde små dyr. Det hele kan minde meget om senere tiders "Pixi"-bøger.

Efterhånden bragtes også historier om småbørns oplevelser i familien.

Et særligt område af stor betydning og medkraftigt engelsk islæt var udklipsting i FJ. Emnets omfang berettiger imidlertid en særskilt undersøgelse.

\section{Vittighedstegninger}

I 1920 'erne og 1930'erne bragte FJ fast vittighedstegninger. Ret hurtigt kom der farver på, og helsider med vittighedstegninger blev almindelige. Måske på grund af copyrightregler blev det her næsten altid anført, fra hvilket engelsk eller amerikansk blad tegningen kom. Først langsomt i slutningen af 1930'erne kom danske vittighedstegninger frem i bladet. En af FJ's hus- tegnere, Carl Røgind, havde dog indtil sin død havde en fast, smal spalte med små vittighedstegninger.

I 1935 havde danske vittighedstegninger vundet stærkt frem. I 1939 havde de helt fortrængt de engelske og amerikanske.

De amerikanske vittighedstegninger kom fra Judge og det gamle Life.

De engelske kom først og fremmest fra The Humorist og The London Opinion, men der sås også tegninger fra Happy Magazine, Pearson's Magazine og Pearson's Weekly.

Alle fem blade blev udgivet af C. Arthur Pearson, Ltd., London.

Da tyske og franske tegninger aldrig sås, var den angelsaksiske dominans i mange år stor og klart angivet. Som dreng opdagede jeg dog aldrig oprindelsen - bladenes navne -, idet disse ofte var samlet diskret nederst på siden. For læseren var det jo normalt ligegyldigt.

\section{Tegneserier, bortset fra Willy-serien}

T aura og Carl Aller hentede inspiration til deres i 1877 startede FJ i bl.a. det tyske blad Die Gartenlaube, der udkom 1853-1944.

Ofte bliver vel sprogkundskaber afgørende for, om en forfatter eller som her en bladudgiver bliver præget af tysk, engelsk eller fransk kultur og derpå bringer den frem i Danmark.

I de første mange årgange af

FJ er den tyske inspiration mærkbar.

Det gælder også tegnede billedserier.

Men efterhånden kom der en del amerikanske tegneserier i FJ. Nævnes kan Mester Puk, Buster Brown, Lises 
Eventyr, Fa'r Pop og hans drenge, Unge Svendsens Oplevelser, Oles Genvordigheder, Hr. Madsens Fataliteter (en hovedserie i FJ: "Clarence", tegnet af Crawford Young, senere af Frank Fogarthy), Sam fra Bjergene samt Jim og Piraterne (en anden hovedserie i FJ: Terry and the Pirates, tegnet af Milton Caniff).

Der var også i begyndelsen af perioden få franske og enkelte danske serier, f.eks. af R. Jørgen Nielsen og bladets egen tegner, Georg Tormer. Men de lignede de tyske serier og savnede vitaliteten og den friske streg i de engelske serier.

Engelske tegneserier bragtes første gang i FJ under 1. verdenskrig. De første i nr. 43, 1915, hvorefter tyske billedserier forsvandt.

Det er umiddelbart fristende at se det som et udslag af engelskvenlig holdning hos Aller under l. verdenskrig. Men der er intet belæg for en sådan påstand. Der kan lige så godt være tale om et resultat af engelsk salgsarbejde eller af Allers eget kendskab til det engelske bladmarked eller lave engelske licensafgifter eller overvejelser om at tilføre bladet et nyt frisk pust i forbindelse med den nye udformning, bladet fik i slutningen af 1913.

Sandsynligvis er der tale om en kombination.

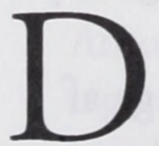

e engelske morsomme tegneserier stod i gæld til den engelske music-hall tradition med dens slapstick og knockabout. I begyndelsen dukkede de morsomme serier og småbørnstegneserierne fra England spredt og næsten tilfældigt op i FJ. Det gjaldt både store og små serier. Det virker som om man afprøvede mulighederne i hele det vældige udvalg, som Amalgamated Press bød på.

Gennem Aller nåede Amalgamated Press' serier også Sverige og Norge, Finland og Island.

Hos Amalgamated Press var tegnerne anonyme og de vidste iøvrigt ikke, at serierne blev eksporteret. FJ angav ikke, at serierne stammede fra England og nævnte ingen tegnernavne. Identifikationen har derfor været svær. Englands største samler og ekspert Denis Gifford har imidlertid - sammen med mine egne undersøgelser på British Library - hjulpet resultater frem.

Over 40 engelske tegneserier har $\mathrm{FJ}$ brugt gennem årene, foruden et utal af småserier, strøet med let hånd rundt i bladet. Småserierne var der navnlig under 1. verdenskrig og i årene lige efter.

Her nævnes nogle af de væsentligste serier fra Amalgamated Press:

1. Charlie Chaplin, fra bladet Funny Wonder, tegnet af Bertie Brown. Første gang kaldte FJ Chaplin for Conrad Conradsen, senere Hr. Schmidt og "jeg" (i to forskellige episoder i samme nr.)

2. Landstrygerne (Den tykke og den tynde): Den vel mest berømte engelske morsomme serie Weary Willie and Tired Tim fra Illustrated Chips, tegnet af Percy Cocking.

3. Dyrepasseren: Jolly Tom the Merry Menagerie Man fra Comic Cuts, tegnet af Percy Cocking.

4. To lystige Fatteres Rejsedagbog, en fort- 


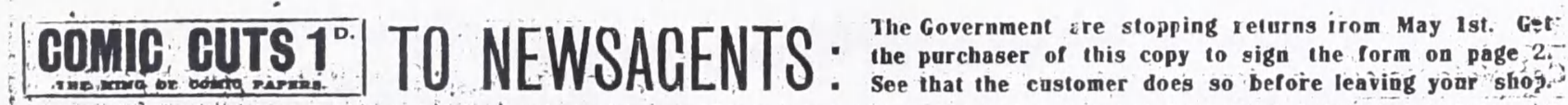

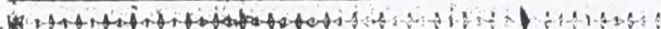
(1) No. 1,408. [Registered.] ONE l'LNNY-liVLRY MONINY.

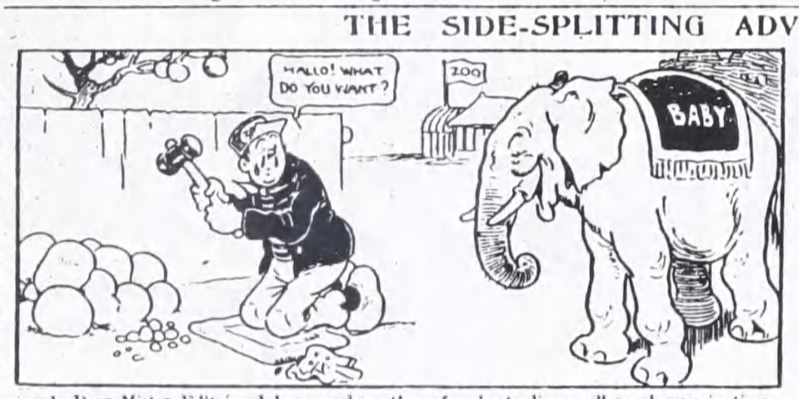

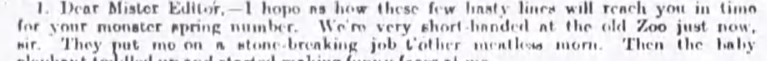

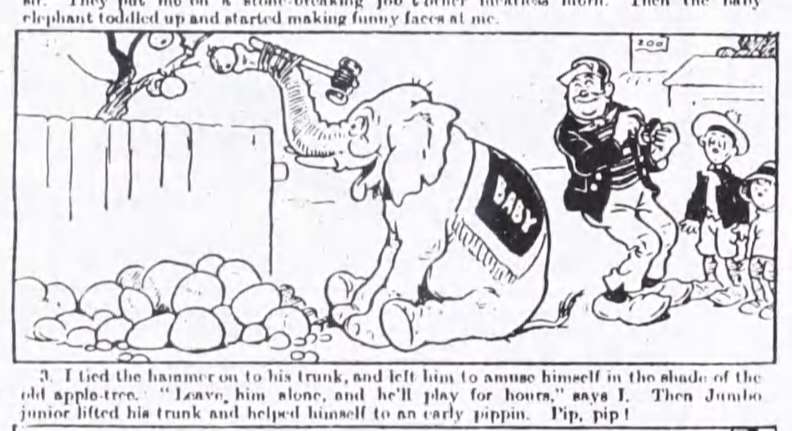

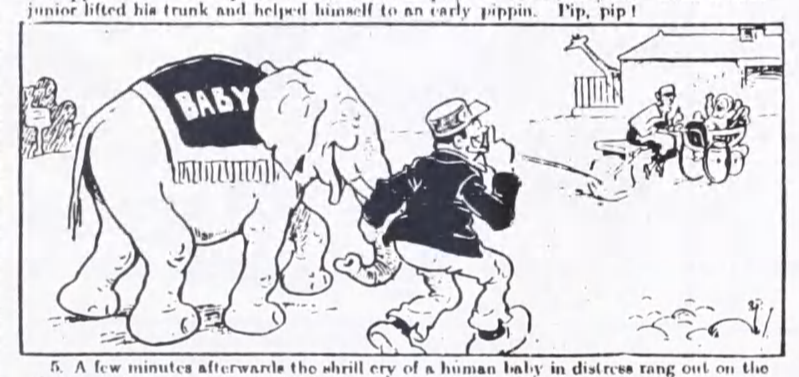

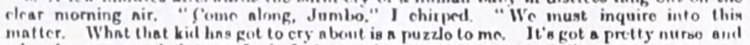

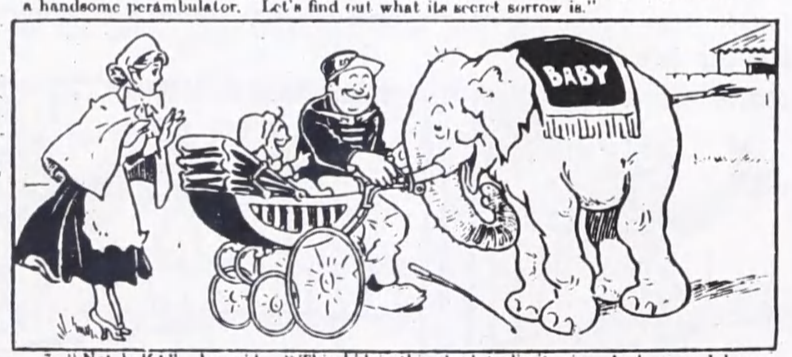

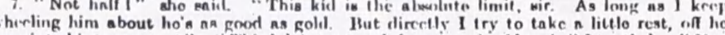
a munt havo an asaigtant."
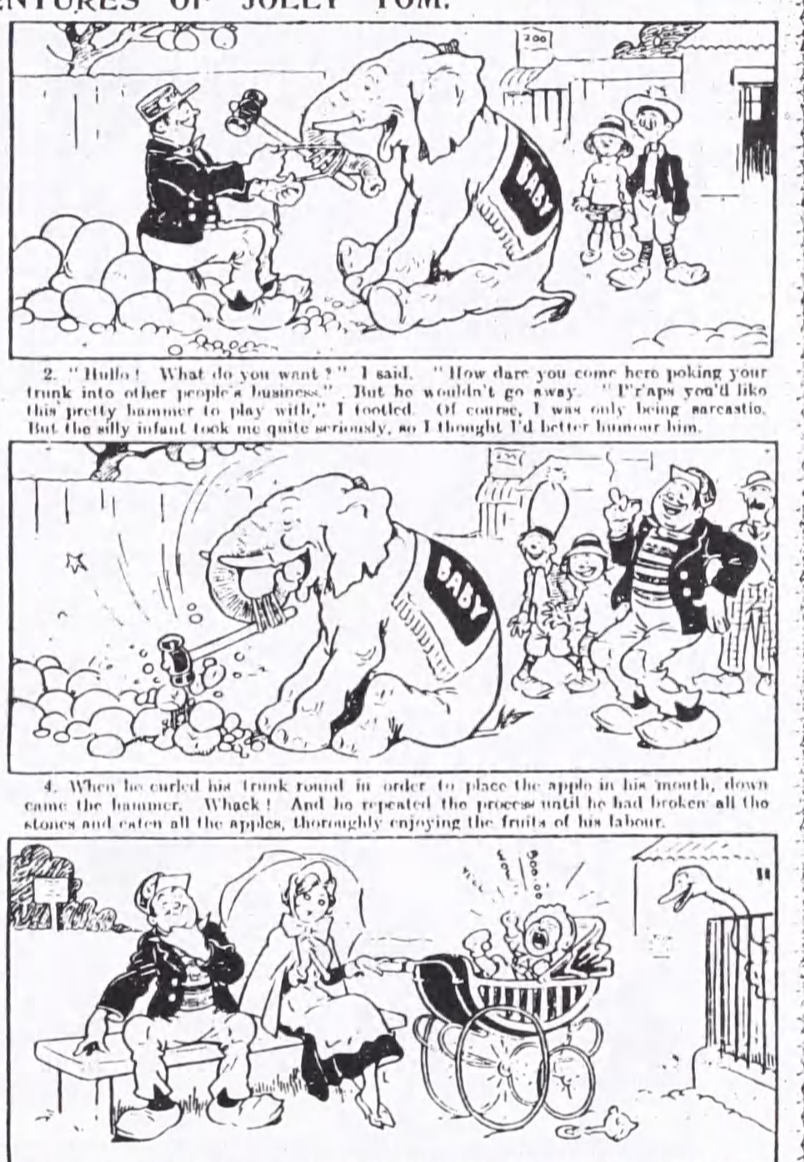

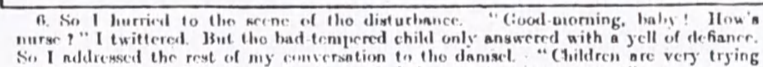
at that age, mins," I conecl. "Dhit yeu find they ket on your nerven,"

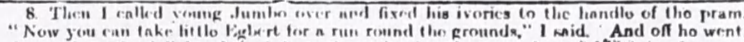

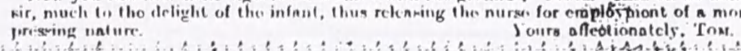


Elefanten er $\mathbf{i}$ Virkeligheden et meget nyttigt Dyr.
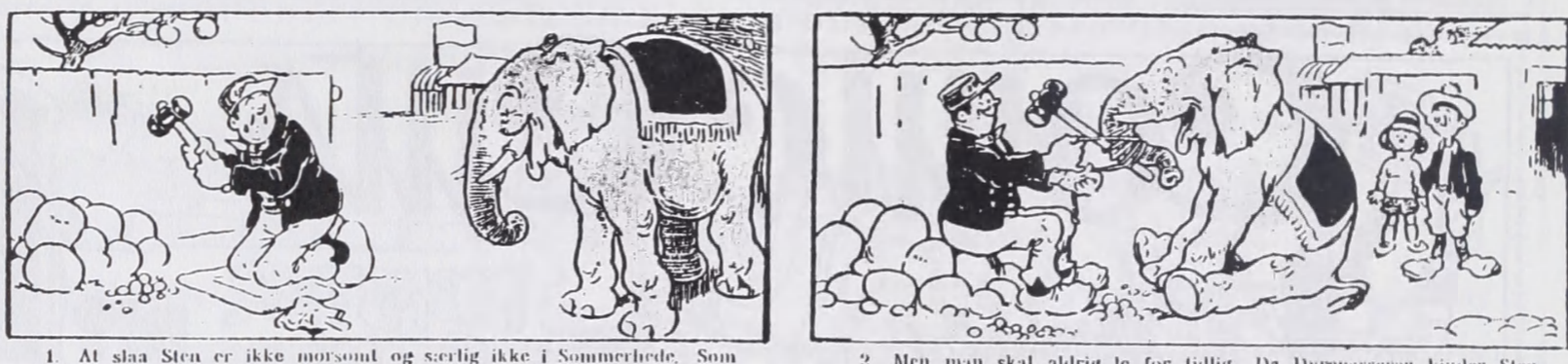

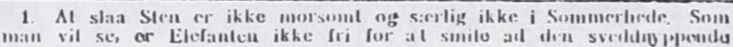

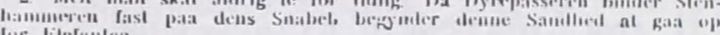
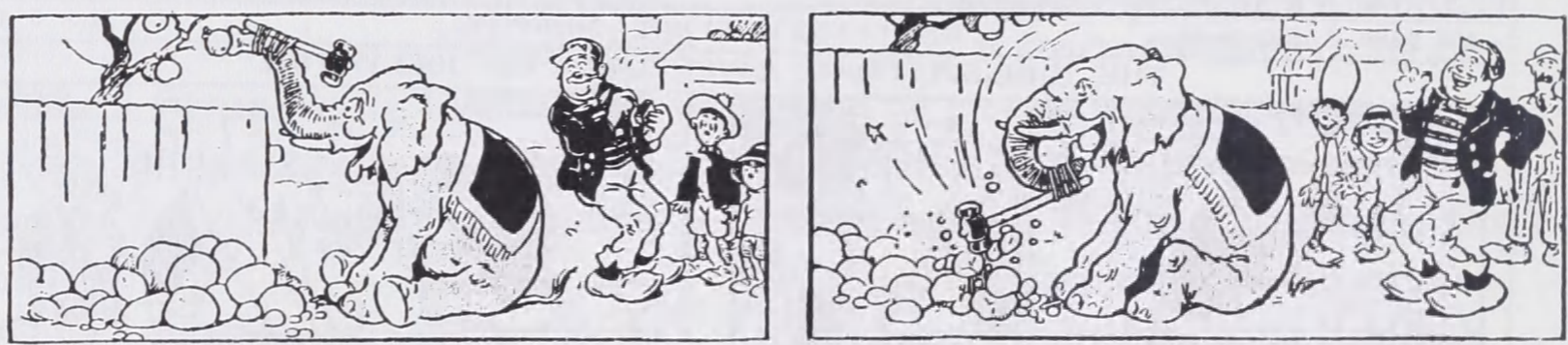

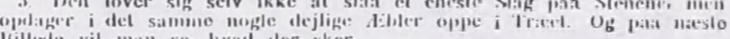

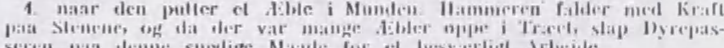
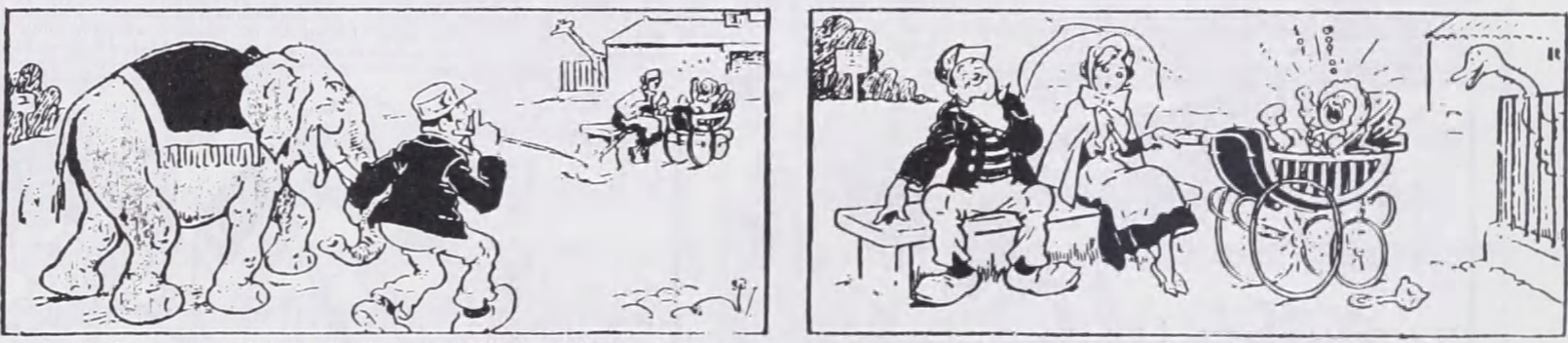

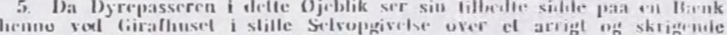

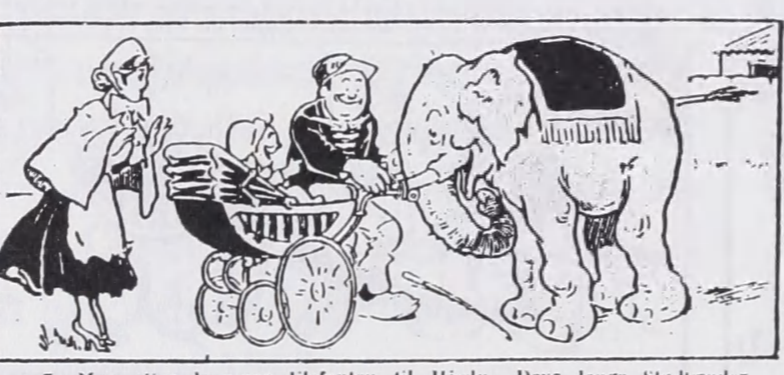

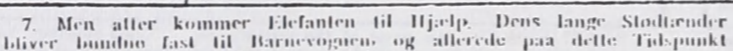

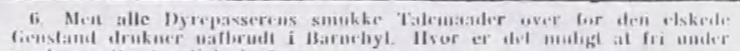

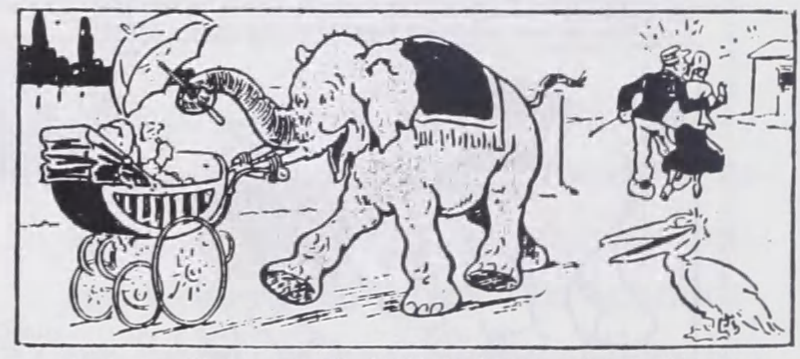

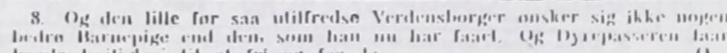

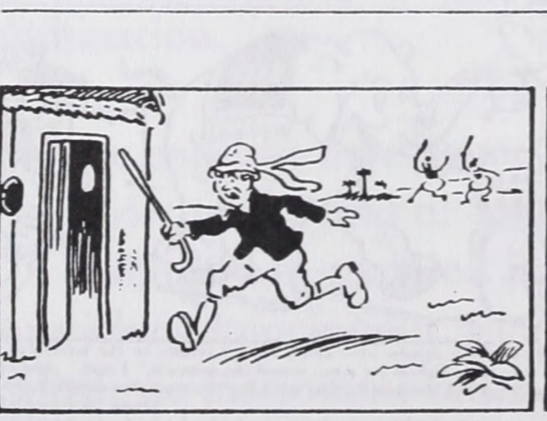

Afrikansk Eventyr.

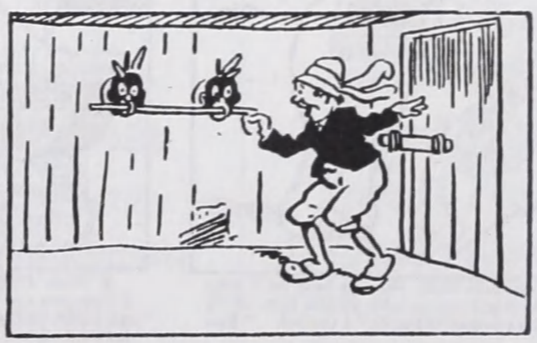

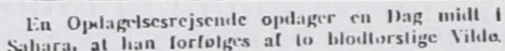

Ilan faar lige akkurat Tid til at smichke Doren
f og sartle Slaacn fur, da to surle Hovester farer

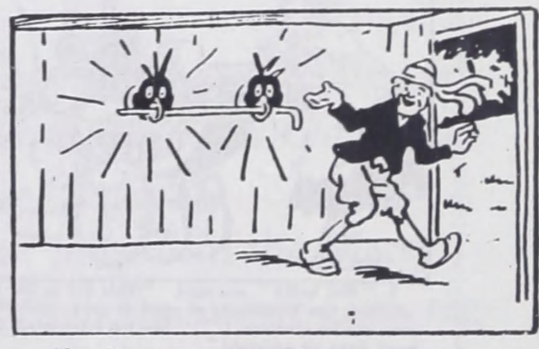

Nen lier ser man, livorfur man nllid bor ga:a med 
løbende, humoristisk serie i farver det havde den ikke i England: The World Wide Wanderings of Basil \& Bert fra The Jester, tegnet af Don Newhouse og Roy Wilson.

5. Tip og Tap: Pitch \& Toss fra Funny Wonder, tegnet af Roy Wilson.

1-3 startede i FJ i efteråret 1916.

2-5 er bragt sammen i én serie i anledning af nytåret - i FJ nr, 52, 1927, p. 46.

6. Den fortryllede skov: The Magic Wood fra The Playbox tegnet af T. Gilson. - Det var en fortløbende småbørnsserie, det meste af tiden i farver. I England kom der hver uge en helside uden farver. I FJ fyldte den danske tegner Harry Nielsen mange afsnit ind. Forklaringen kendes ikke. Men måske har Valutacentralen fra 1930'ernes begyndelse været karrig med tildelingerne, eller hustegneren Harry N. var måske på fast løn hos FJ og skulle beskæftiges.

7. Bamse fra Dukkeland (senere: Bamse fra Eventyrland - senere igen: Bamse og DukkeLise): Teddy in Toyland (og senere titler) fra Tiny Tots tegnet af Vera Bowyer. - En fortløbende småbørnsserie i farver. Også her fyldte Harry Nielsen mange afsnit ind, idet FJ bragte en hel side hver uge, mens Tiny Tots kun havde en halv side. I 1939 var der 24 danske og 28 engelske afsnit i FJ. Serien blev iøvrigt senere helt dansk. Men selv under Besættelsen var der engelske afsnit - antagelig via "Allers" i Helsingborg.
I 1935 var der ikke længere morsomme engelske serier i FJ.

Men der var stadig engelske småbørnsserier - helsides og i farver. Efter Den fortryllede Skovs ophør i 1934 kom der andre. Bamse fra Dukkeland startede i 1935.

FJ havde en fast politik gående ud på, at tegneseriers talebobler blev fjernet, tildels engelsk inspireret: Tekst skulle kun bringes under billederne. Overensstemmende hermed brugtes ordet tegneserier ikke. De kaldtes kun serier. Fra og med 1937 kaldtes de i bladets indholdsfortegnelser billedserier. Tegneren Jørgen Mogensen har senere uelskværdigt kaldt det "sådan lidt i retning af foredrag med lysbilleder".

Serien Jim og Piraterne blev ret hårdt behandlet efter dette princip. Der har dog været enkelte undtagelser: I FJ 1920 (nr. 34, s. 24) præsenteredes en helsides amerikansk serie med talebobler og med følgende overskrift: "De optrædende Personer 'taler' selv". I nr. 11921 , kaldes de "De talende Billeder". Men det forsvandt hurtigt igen. I 1930'erne var der i Den fortryllede skov både talebobler på billederne og tekst nedenunder.

Tegnerne dengang var naturligvis ikke "fotografiske", men det hørte med til håndværket, at baggrunden blev tegnet med. Lidt nostalgisk, hyggeligt og lidt oplysende kan man - som danske børn dengang - få en indføring i engelsk miljø dengang: påklædning, engelske huse indvendigt: fireplace, stort komfur, tændt kammerstage i mangel af elektrisk lys, gadebilleder med lygtepæle, forretninger, restauranter med orkestre, spor- 
vogne, busser og biler - samt fly, skibe og luftskibe. Det vækker mindelser om Chaplins gamle film.

\section{Billedserien Willy på Eventyr}

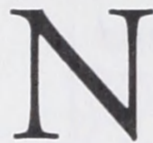

år denne serie fortjener et særskilt afsnit er det, fordi den var FJ's flagskib på tegneserie-

fronten og løb næsten uafbrudt fra 1923 til 1977. En enkelt side i 1922 samt sider $i$ et juleekstranummer i 1922 var en slags prøve, taget fra serien Rob the Rover. Fra 1923 til 1941 var Willy-serien overvejende engelsk, som følgende viser:

Nr. 13, 1923 - 43, 1924:Rob the Rover fra bladet Puck (A.P.), tegnet af Walter Booth, men mest af Vincent Daniel.

Nr. 44, 1924 - 22, 1925: Ingen Willy.

Nr. 23, 1925 - 25, 1927: Rob the Rover, tegnet af Walter Booth.

Nr. 26, 1927 - 44, 1928: The Adventure Seekers, fra Lot-ó-Fun (A.P. ), tegnet af Walter Booth.

Nr. 45, 1928 - 17, 1935: Rob the Rover, tegnet af Walter Booth.

Nr. 18, 1935 - 4, 1936: Quest of the Grey Hawk fra Butterfly (A.P. ) tegner ukendt, også i England. Hårdt redigeret af FJ.

Nr. 5, 1936 - 29, 1936: Dansk produceret almindelig tekstroman om Willy - forfatter ukendt - ledsaget af en tegning af Harry Nielsen hver uge.

Nr. 30, 1936 - 43, 1936: Ingen Willy. Nr. 44, 1936 - 22, 1938: Rob the Rover (Booth). Relanceringen af serien i FJ skete i forbindelse med bladets modernisering.

Nr. 23, 1938 - 24, 1939: The Golden
Arrow fra Puck (A.P. ), tegnet af Reg Perrot i moderne stil.

Nr. 25, 1939 - 29, 1941: Rob the Rover (Booth).

Nr. 30, 1941 -Ingen engelsk Willy mere.

Walter Booth har tegnet mange andre smukke spændingsserier og også småbørnsserier, som er ukendte herhjemme.

Rob the Rover startede i Puck i

maj 1920 og stoppede i England i maj 1940. Både i begyndelsen og senere udelod FJ mange afsnit af serien, og ofte er enkeltbilleder skåret væk eller ændret. Bl.a. er jagt- og fiskeriscener udgået. Det var iøvrigt en kultiveret og sober serie. I næsten hele perioden var serien i farver $\mathrm{i}$ FJ. De oprindelige engelske serier var sort-hvide.

Ikke mindst Willyserien, hvis oprindelse - og sammenvævningen af flere engelske serier - var (blev holdt?) helt ukendt for danske læsere, gav et stærkt engelsk indslag i FJ. Serien var en 'imperieserie'. Ofte blev Willy assisteret af en nærliggende engelsk garnison. I 1937 bliver Willy og hans selskab af filmfolk modtaget af en Lord Mayor i en engelsk by.

Om seriens mulige betydning for børns og unges forestillingsverden bemærkes, at serien hurtigt fik en fremtrædende placering i FJ, med en helside i farver hver uge. Serien appellerede stærkt til børn og unge, idet den focuserede meget på tidens nye spændende fænomen: flyvemaskinen, der naturligt måtte fascinere de unge. Serien var verdens første "adventure strip".

Når engelske Willy stoppede i Danmark i 1941, er årsagen, at Rob the 
Rover-serien ophørte i maj 1940, idet bl.a. A.P. blev pålagt voldsomme papirrestriktioner som følge af, at forsyningerne fra især Finland stoppede, da Norge blev tysk besat.

A.P. stoppede mange blade på én gang. Slutningen på Rob the Rover blev - nok som følge af en forvirring hos A.P.'s stab - underlig. Der forekom et par sider i England, som FJ ikke bragte, mens FJ bragte originale afsluttende sider i 1941, som aldrig sås i England, men havde sammenhæng med disse sider! FJ kan have fàet de afsluttende sider via "Allers" i Helsingborg. - Serien blev aldrig genoptaget i England.

\section{Afslutning}

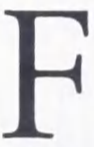

ordelingen af stof i FJ ændrede sig naturligvis over årene. Ved en sammenligning mellem FJ 1925 og 1930 ses således vedrørende stof fra England: I 1930 er der færre udklipsting m.v. men mange mosaikopgaver (sammenlægningsopgaver), færre malerier og tegninger som selvstændige indslag samt færre morsomme tegneserier. Men i 1930 er der nu helsider med eventyr ledsaget af engelske tegninger i farver, engelske vittighedstegninger skiftende med amerikanske, (siden 1927): engelske ungdomsromaner - med engelske tegninger - og mere fremtrædende lay-out for engelske noveller i næsten hvert nr. og næsten altid med engelske tegninger.

I min søgen efter 'missing links' mellem engelske blade/magasiner og FJ samt efter oplysninger om FJ's historie har jeg fået værdifuld hjælp af Emil Johansson, Jørgen Mehlskov, Philip
Den hyppige brug af engelsk anonymt stof over for de mest modtagelige læsere, børn og unge: tegninger fra engelsk historie, småbørnshistorier, ungdomsromaner, tegneserier og udklipsting - må antages at have påvirket børn og unge, uden at nogen kerede sig om det. Det må have givet en vis tilvænning til engelske forhold og mennesker. I forhold til voksne har den lille ugentlige dosis vel heller ikke været ganske uden virkning.

I denne forbindelse må det erindres, at særligt i den her undersøgte periode var indholdet af ugeblade og børnebøger af væsentlig betydning som påvirkningsfaktor for unge, fordi der kun fandtes små og få børneblade (og næsten kun uspændende sort-hvide tryk).

Der var kun én radiokanal og børneprogrammerne var ofte meget saglige. Grammofonplader var dyre. Der var biografer, men ingen tegneserieblade, ingen båndoptagere, intet TV, ingen video, CD, CD-rom, Internet, Computerspil eller playstations. Scenen tilhørte helt overvejende ugebladene, børnebøgerne og i nogen grad de kulørte hefter.

Den samlede engelske påvirkning af FJ 's læsere var naturligvis afhængig af bladets oplag i perioden. De tidligste oplagstal er fra 1927-31: 220-240.000 årligt (iflg. Ejler Alkjærs bog). I 1935 var oplaget 183.000 og i 1939: 199.000.

Treschow, Michael Aller (Aller Press A/S), Denis Gifford (England) og Norman Wright (England). 
Noter

1) Nogle tegninger i FJ, der stammer fra det engelske The Wide World Magazine:
W.W.

April 1927

May 1927

May 1927

June 1927

Sep 1927

Feb 1928

Feb 1928

Feb 1928

Feb 1928

April 1928
FJ

p. 33

p. 86

p. 167

p. 213

p. 495

p. 373

p. 401

p. 407

p. 411

p. 43
Nr. 36, 1927, p.7

Nr. 30,1927 , p. 9

Nr. 33, 1927, p. 10

Nr. 33,1927 , p. 10

Nr. 48, 1927, p. 11

Nr.17, 1928, p. 7

Nr. 17,1928 , p. 7

Nr. 17, 1928 p. 7

Nr. 27,1928 , p. 11

Nr. 22, 1928, p. 7

2 ) Familie Journalens 100 års julbilæum: $\mathrm{Nr}$. 4, 1977, side 22-24 + navnlig 87.

Bogen - og ellers - Allers af Victor Schlytter (A/S Allers Familie-Journal, Oslo, u.år (1984), 205 sider), p. 187, jfr. 179.

\section{Litteratur}

Alkjær, Ejler: Studier i eftersporgslen på det danske ugebladsmarked. Med et pressehistorisk bidrag af Ulf Kjær-Hansen. 1961. - Denne forskningsopgave var direkte inspireret af Dir. Svend Aller.

Aller, Michael B.: Carl Allers Etablissement pp. 13-24. I: Sådan skabtes Danmarks store virksomheder. Red .: Bertel Bernhard. Heri også: Johan Severin: Gutenberghus gruppen pp. 367-376. 1988.

Andersen, Verner E.: Artikler og indlæg om engelske tegneserier, herunder Willyserien, i FJ: aktuelt's kronik 18.9.1976, Kulorte sider okt. 1976 og aug. 1982, Komix nov. 1983, Seriejournalen dec. 1991 samt Newsletter from The Association of Comics.

Entusiasts (publ. by Denis Gifford, London) July 1981, Jan/Feb. 1982, Sep 1985, Jan/Feb. 1987, April 1987 og June/July 1988.
3) Nogle engelske noveller og deres forekomst i FJ:

Engelsk

The Strand Magazine

Jan.1927, p.41

Jan. 1927, p.30

Dec. 1927,p. 624

Dec. 1927,p. 609

Jan. 1928, p. 94

Feb. 1928,p. 182

Mar. 1928,p. 297

May 1928 p. 452

Oct.1928, p.406

Feb. 1936, p. 446

Jun. 1937, p. 210

The Windsor Magazine

Jul.1928, p. $158 \quad$ Nr. 6, 1929, p. 30

The Wide World Magazine

Sep.1927, p.422 Nr. 43,1929 , p. 23

May 1928 , p. 86 Nr. 25,1929 , p. 27

Pearson's Magazine

Jan. 1930 , p. $4 \quad$ Nr. 41,1930 , p. 30

Apr. 1933, p. 370 Nr. 28, 1933, p. 26

Bäck, Folke: Barndomsminnen: pp. 22-51:

Barndomens Allersminnen. Karlstad. 1987.

Bäck, Folke: 90 Allersmodeller; Karlstad, 1992 (medindb: Folke Bäck: 350 gamla lekar).

Bruun, Osvald: Osvald Bruun fortæller. [om tiden fra 1874 til o. 1. verdenskrig som bydreng og kemigraf hos Aller]. 1964.

Dahlström, Britt: Familjens världsbild (Allers 1919), pp. 65-100. I: Veckopressen i Sverige, analyser og perspektiv, med indledning af professor Per Rydén. Löderup, Sverige: Förlagshuset Mälarhusgården for Lunds Universitet, Litteraturvetenskapliga Institutionen, Afd. för pressforskning, 1979.

Dansk litteraturhistorie bind 6, pp. 426-436: Lidt om F.J.'s oplag i 1800-tallet og meget om F.J.'s romaner dengang. - bind 7, pp. 196-208: Især om Hjemmet og FJ. - bind 8, pp. 168-171 og 368-370: Om tegneserieblade og ugeblade, især Søndags-B.T. og EVA. 1984-1985. 
Dansk Mediehistorie, red. Klaus Bruhn Jensen, bind 1-3. 1196-1997.

Die Gartenlaube, Facsimile Querschnitt durch eingeleitet von Friedrich Sieburg. Bern Stuttgart Wien: Facsimile-Querschnitte durch alte Zeitungen und Zeitschriften, der erste Band, 1963.

Drotner, Kirsten: Drengemagasiner - magasindrenge: masselitteratur for drenge $i$ det 19. arhundredes England. 1977.

Drotner, Kirsten: English Children and Their Magazines, 1751-1945: bl.a. pp. 125- 130 om The Amalgamated Press Ltd. (London). New Haven and London Yale University Press, 1988.

En kulturhistoria: - Allers Förlag 100 år 18941994. Text: Sven Bergquist. Helsingborg, 1994.

Frølund, Jørgen: Artikel om den allersidste, dansktegnede Willyserie, Kulørte sider, maj 1982.

Gifford, Denis: The British Comic Catalogue 1874-1974. London, 1975.

Gifford, Denis: Encyclopedia of Comic Characters. Harlow, Essex, 1987.

Heft, Tage: 16 Stormand $i$ dansk Erhverv: pp. 195-206 om Carl Aller, uden år.

Juncker, Beth: Kvinder - klasser og ugeblade. især pp. 55-79, 123-125, 129, 141-144. 155156, 159, 184-185 og 189-191. 1976.

Lemche, H.J.: Sophienholm og familien Aller. Efter optegnelser fra dir. Valdemar Aller. Med slægtstavle vedrørende Allerfamilien. Lyngby-bogen 1974-75. 1975.
Lofts, W.O.G. and Adley, D.J.: The Men Behind Boys' Fiction. London, 1970.

Mehlskov Jørgen: Hvidbog om en kulørt serie: Willy på Eventyr. 1982. - Der overvejes et tillæg til supplering og korrektion af en del faktuelle oplysninger.

Mehlskov, Jørgen: Dukketeater i FJ og Hjemmet, Komplet oversigt 1914-1941 i billeder. 1984.

Mehlskov, Jørgen: Udklipsark m.v. i FJ 19131944: Del 2, kartonarkene (del 1 ikke udkommet). 1991.

Pesersen, Mogens E.: (under medvirken af Michael B. Aller og Kjeld Damgaard): 125 år - Carl Allers Etablissement 4. april 1873 - 4. april 1988. 1998.

Petersen, Jens Louis: Opslag '23: 2 upaginerede sider om Willytegneserien i FJ fra 1923, og om at dens oprindelse er ukendt; Opus i 75 satser. 1975.

Poulsen, Karen Klitgaard: Organisering af hverdagsliv og livsstil, ugeblade, magasiner og fagblade: Rapport udarbejdet for, og udgivet af, Statsministeriets Medieudvalg, 1995.

Schlytter, Victor: - og ellers - Allers. Trekk fra A/ $S$ Allers Familie-Journals Historie. Oslo, (1984).

Treschow, Philip: Gemt eller glemt? Set årstal på et billede 1886-1986: Sider aftrykt fra aviser, ugeblade, julehefter m.m.: pp. 51-52, 85-86 og 95-96 om FJ. 1986.

Warner, Philip: The Best of Chums. London, 1978. 